\title{
STRATEGI KOMUNIKASI PEMASARAN THE GOODS DEPT UNTUK MENARIK PEMBELI MILLENIAL (Studi Pada The Goods Dept Pondok Indah Mall)
}

\author{
Faradina Aulia Putri ${ }^{1)}$, Nuriyati Samatan ${ }^{2)}$ \\ Fakultas Komunikasi Universitas Gunadarma \\ faradinauliaputri@yahoo.com ${ }^{1}$ \\ nuriyatisamatan@gmail.com²
}

\begin{abstract}
Abstrak
Toko retail sekarang mulai digandrungi masyarakat terutama remaja bahkan yang sudah dewasa, karena banyak pilihan dan lengkap. Strategi komunikasi pemasaran tentunya dibutuhkan setiap toko atau perusahaan yang ingin produknya dikenal oleh masyarakat. Berdasarkan alasan tersebut, memotivasi peneliti untuk mengkaji bagaimana Strategi Komunikasi Pemasaran The Goods Dept untuk Menarik Pembeli Millenial. Penelitian ini bertujuan untuk mengetahui bagaimana strategi komunikasi pemasaran The Goods Dept dalam menarik pembeli millenials. Dalam penelitian ini peneliti menggunakan teori Integrated Marketing Communication yang mempunyai konsep dasar pengembangannya mengenai strategi komunikasi pemasaran dan empat bauran pemasaran yang terdiri dari product, price, place, dan promotion. Metode yang digunakan dalam penelitian ini adalah kualitatif purposive sampling dengan mengambil sampel dengan pertimbangan tertentu. Berdasarkan hasil penelitian yang telah dilakukan, maka dapat ditarik kesimpulan mengenai hasil penelitian yaitu dengan selalu mengikuti trend zaman sekarang setiap tahunnya dan mempunyai visi utama untuk selalu mendukung para brand lokal, memanfaatkan teknologi yang ada untuk berinteraksi dengan konsumen terutama para millenials yaitu dengan menggunakan media sosial Instagram, web store, directmarketing, berinteraksi dengan konsumen, sponsorship, dan corporateidentity
\end{abstract}

Kata Kunci: Strategi Komunikasi Pemasaran, Menarik Pembeli, Millenials.

\begin{abstract}
Retail stores are now starting to be loved by the community, especially teenagers and even adults, because there are many choices and complete. Marketing communication strategy is certainly needed by every store or company that wants its products known by the public. Based on these reasons, motivating researchers to study how The Goods Dept's Marketing Communication Strategy to Attract Millennial Buyers. This study aims to find out how The Goods Dept's marketing communication strategy is to attract millennial buyers. In this study, researchers used the theory of Integrated Marketing Communication which has a basic concept of development regarding marketing communication strategies and four marketing mix consisting of product, price, place, and promotion. The method used in this research is qualitative purposive sampling by taking samples with certain considerations. Based on the results of research that has been done, it can be concluded about the results of research that is to always follow the current trend every year and have a main vision to always support local brands, utilize existing technology to interact with consumers, especially millennials, namely by using social media Instagram, web store, directmarketing, interacting with consumers, sponsorship, and corporate identity
\end{abstract}

Keywords: Regional House of Representatives, Right of Initiative, Local Regulation

\section{PENDAHULUAN}

Seiring dengan perkembangan zaman yang semakin pesat, berdirinya perusahaan atau toko retail bukan lagi hal yang baru. Retail atau yang bisa disebut toko yang menjual barangatau produk dari 
brand lain sudah masuk dalam dunia bisnis masa kini. Brand yang dimaksud disini pun banyak macamnya, mulai dari produk lokal sampai produk dari luar negeri.

Berkembangnya perusahaan atau toko retail sekarang mulai di gandrungi masyarakat terutama remaja bahkan yang sudah dewasa, mereka menyukai produkproduk yang disediakan di The Goods Dept karena banyak pilihan dan termasuk salah satu toko retail yang lengkap.

Strategi komunikasi pemasaran tentunya dibutuhkan setiap toko atau perusahaan yang ingin produknya dikenal oleh masyarakat. Berdasarkan alasan tersebut, memotivasi peneliti untuk mengkaji bagaimana Strategi Komunikasi Pemasaran The Goods Dept untuk Menarik Pembeli Millenial.

\section{KERANGKA TEORI \\ Integrated Marketing Communication (IMC)}

IMC (Integrated Marketing Communication) adalah sebuah konsep dari perencanaan komunikasi pemasaran yang memperkenalkan nilai tambah dari rencana komprehensif yang mengevaluasi peran strategis dari berbagai disiplin komunikasi-misalnya periklanan umum, respon langsung, sales promotion, dan PR dan mengombinasikan disiplin-disiplin ini untuk memberikan kejelasan, konsistensi dan dampak komunikasi yang maksimal.

\section{Konsep Dasar Pengembangan berbagai Program IMC}

Konsep Dasar Pengembangan berbagai Program IMC terdiri dari Direct Marketing, Sales Promotion, Public Relation, Personal Selling, Advertising, Publicity, Event/ Sponsorship dan Interactive Marketing. Konsep dasar tersebut digunakan untuk mengetahui bagaimana strategi komunikasi pemasaran yang dilakukan oleh The Goods Dept.

\section{P Bauran Pemasaran}

Manajemen pemasaran mengenal empat strategi pemasaran yang lazim disebut bauran pemasaran 4P, yaitu Produk (product), Harga (price), Tempat (place), dan Promosi (promotion.

\section{METODE PENELITIAN}

Metode penelitian yang digunakan adalah metode kualitatif. Penelitian yang digunakan yaitu penelitian kualitatif deskriptif. Penelitian kualitatif deskriptif adalah berupa penelitian dengan metode atau pendekatan studi kasus (case study). Data studi kasus dapat diperoleh dari semua pihak yang bersangkutan, dengan kata lain dalam studi ini dikumpulkan dari berbagai sumber (Nawawi, 2003).

Paradigma yang digunakan dalam penelitian ini adalahkonstruktivisme, Teori konstruktivisme menyatakan bahwa individu melakukan interpretasi dan bertindak menurut berbagai kategori konseptual yang ada dalam pikirannya. Realitas tidak menunjukkan dirinya dalam bentuknya yang kasar, tetapi harus disaring terlebih dahulu melalui bagaimana cara seseorang melihat sesuatu (Morissan, 2009:107)

Pengambilan sumber data dilakukan dengan cara purposive sampling teknik pengambilan sampel sumber data dengan pertimbangan tertentuPerkembangan tertentu ini misalnya orang tersebut yang dianggap tahu tentang apa yang kita harapkan atau mungkin dia sebagai penguasa sehinggaakan memudahkan peneliti menjelajahi obyek atau situasi yang diteliti.

\section{HASIL PENELITIAN \\ Strategi Komunikasi Pemasaran}

\section{Advertising}

Advertising yang diterapkan The Goods Dept yaitu menekankan pada sosial media Instagram, karena Instagram memberikan respon engagemanet yang baik. Selain Instagram, The Goods Dept juga memakai sms LBA, atau LocationBasedAdvertisement dan memakai conventional dengan contoh misalnya engage dengan mall dan The Goods Dept juga kerja sama dengan thirdparties, seperti halnya dengan Jenius

\section{Public Relation dan Publicity}

The Goods Dept tidak mempunyai Public Relation, karena mereka di fokuskan di marketing komunikasi yang fungsinya itu untuk mengurus publicity, brandawarenss, promotion dan 
brandreposition. Untuk publicity The Goods Dept melakukan kegiatan bersama mall atau melakukan kerja sama dengan beberapa influencer. The Goods Dept juga partnertship dengan kolaborator untuk membuat merchandise.

\section{Personal Selling}

Personal Selling dilakukan The Goods Dept melalui bagian operasional mereka yang ada di toko, jadi para karyawannya yang berinteraksi dengan konsumen. Jika konsumen mempunyai pertanyaan atau butuh bantuan, karyawan yang membantu dan bahkan memberikan saran untuk konsumen yang ingin membeli suatu produk. Karyawan-karyawan tersebut tentu harus bisa meyakinkan konsumen untuk membeli produk tersebut dengan meyebutkan kelebihan dan keunggulan yang dipunya atau bahkan dengan ada promosi untuk produk tersebut.

\section{Direct Marketing}

DirectMarketing yang The Goods Dept lakukan yaitu dengan berinteraksi dengan konsumen melalui e-mail atau newsletter. The Goods Dept mempunyai webstore, jadi para konsumen yang ingin belanja online bisa langsung mengunjungi webstore, dan berinteraksi melalui e-mail. Selain webstore, mereka juga mempunyai customercaredimana konsumen bisa memberikan keluhan atau menanyakan size dari suatu brand atau brand apa yang baru masuk. Begitu juga halnya dengan Instagram, theGoods Dept mempunya admin Instagram yang di tugaskan untuk membalas pertanyaanpertanyaan konsumen di kolom komen Instagram.

5. Sponsorship

Pemberian sponsor pada suatu kegiatan dapat menjadi strategi komunikasi pemasaran yang baik. Hal ini dapat meningkatkan brandawareness dan reputasi perusahaan itu sendiri. The Goods Dept pernah memberikan sponsor dan yang tentunya kegiatan acara yang mensupport brand lokal seperti visi mereka.
6. Corporate Identity

Pembangunan citra perusahaan juga penting untuk rencana jangka panjang perusahaan. The Goods Dept ingin mengedepankan brand lokal, dimana menurut mereka brand lokal juga bisa sama baiknya dengan brandinternational. The Goods Dept ingin menjadi satu-satunya yang supportbrand lokal, mereka ingin menjadi garda depan dimanabrand lokal bisa eksis dan memperkenalkan produk mereka lewat Goods Dept.

7. Packaging

Kemasan produk dapat menjadi hal yang penting dalam strategi komunikasi pemasaran produk. Kemasan yang menarik dapat mempengaruhi keputusan konsumen dalam membeli produk. Komunikasi ini bisa dalam bentuk desain, warna serta bentuk dari kemasan produk tersebut. The Goods Dept mempunyai caranya sendiri untuk mengemas produk, paperbag sampai bagaimana gaya tokonya mereka. The Goods Dept mempunyai SOP sendiri perihal kemasa produk, apapun brand yang dibeli, konsumen tetap membawa kemasan The Goods Dept, jadi yang dilihat bukan produk apa yang konsumen beli, tetapi konsumen habis belanja di Goods Dept.

8. Word of Mouth

The Goods Dept selalu menjajah internal mereka, jadi karyawankaryawan mereka yang harus merepresentasikan barang-barang yang ada. Selain itu The Goods Dept juga bekerja sama dengan brand-brand besar jadi mereka bisa bergaul dan mengatakan ada produk apa saja yang baru di store. The Goods Dept mempunya karyawan-karyawan yang masih muda dan mengerti trend, jadi mereka bisa mudah keep in touch dengan orang luar

\section{P Bauran Pemasaran}

\section{Product}

The Goods Dept menjual banyak sekali produk apparael, fashion dan produk yang mendukungnya, jadi bisa dikatakan The Goods Dept ini menjual whole package, yang dimaksud whole 
package disini adalah, siapapun konsumennya, bisa mencari produk dari atas sampai bawah, misalkan baju, celana, sepatu bahkan hingga aksesoris seperti jam tangan, kaos kaki. Produk yang dijual di The Goods Dept mengutamakan brand lokal, tetapi juga tetap ada produk dari international brand. The Goods Dept menginginkan konsumen mengetahui brand lokal sama bagusnya dengan international brand.

2. Price

Harga dan produk yang diterapkan dari satu store ke store lainnya berbeda, seperti hal nyastore di Pondok Indah Mall, akan berbeda dengan store yang ada di Pacific Place, di karenakan pasarnya pun berbeda.Harga yang diterapkan ad adari yang sangat murah sampai sangat mahal tergantung dari produknya.

3. Place

Store-store yang dibuka di berbagai Mall di Jakarta juga dipikirkan matangmatang oleh pihak The Goods Dept, mereka surveymall mana saja yang sekiranya menjangkau pasarnya The Goods Dept. Pondok Indah Mall contohnya, PIM adalah mall yang sedari dulu anak muda gaulnya ke sana, dan PIM termasuk salah satu Mall yang paling besar dengan pengunjung paling ramai. Kalangan millenials banyak yang mendatangi PIM. Sama hal nya dengan store yang di Pacific Place, kali ini The Goods Dept mengincar konsumen dari kalangan menengah ke atas, tentunya barang atau produk yang disediakan juga berbeda, begitu juga dengan harganya. The Goods Dept menyesuaikan dengan lokasi storenya ada dimana, dengan begitu mereka bisa mendistribusikan produk yang mana untuk di PIM dan produk mana untuk di Pacific Place.

\section{Promotion}

Promosi yang di terapkan di The Goods Dept yaitu 360 integratedpromotion yang berarti mereka menggunakan semua channel yang ada, seperti sosial media yaitu Instagram, menggunakan Influencer dan karena The Goods Dept menjalin hubungan baik dengan mall- mall tersebut, jadi mereka bisa bekerja sama. Promotiontools yang ada di mall bisa dipakai oleh The Goods Dept, seperti banner LED, poster yang dipasang di beberapa titik

\section{KESIMPULAN}

Berdasarkan hasil penelitian yang telah dilakukan, maka dapat ditarik kesimpulan mengenai hasil penelitian yaitu strategi komunikasi pemasaran The Goods Dept yang utama yaitu dengan selalu mengikuti trend zaman sekarang setiap tahunnya dan mempunyai visi utama untuk selalu mendukung para brand lokal. The Goods Dept tentu juga mempunyai bagian penting seperti marketingcommunication dan designer yang selalu berusaha untuk memberikan cara-cara demi meningkatkan citra jangka panjang dan design produk yang terbaik untuk para konsumen. The Goods Dept memanfaatkan teknologi yang ada untuk berinteraksi dengan konsumen terutama para millenials yaitu dengan menggunakan media sosial Instagram.

Strategi komunikasi pemasaran yang dilakukan The Goods Dept dengan berbagai bentuk yaitu advertising dengan melalui Instagram, publicity dengan melakukan kerja sama dengan mall, personal selling melalui karyawannya, directmarketing yaitu adanya web store untuk berinteraksi dengan konsumen, sponsorship, corporateidentity yang dimana The Goods Dept ingin mengdepankanbrand lokal, packaging yang mempunyai SOP dan wordofmouth yang dilakukan oleh para karyawannya yang harus bisa merepresentasikan produk-produk yang ada. Berbagai bentuk komunikasi pemasaran tersebut merupakan strategi untuk menarik para konsumen terutama konsumen millenials.

\section{SARAN}

Berdasarkan penelitian yang telah dilakukan dan melihat dari hasil penelitian, maka adapun saran yang diberikan sebagai berikut.

1. Kepada mahasiswa/l mengenal penelitian tentang strategi komunikasi pemasaran suatu toko retail dalam menarik pembeli yaitu dalam 
penelitian ini strategi komunikasi pemasaran The Goods Dept untuk menarik pembeli millenials

2. Peneliti selanjutnya diharapkan mampu melakukan penelitian lebih lanjut diluar strategi komunikasi pemasaran untuk menarik pembeliMillenials

3. The Goods Dept sebagai toko retail diharapkan untuk selalu berinovasi dalam mempromosikan produknya dan selalu mendukung brand lokal.

4. The Goods Dept diharapkan untuk memperhatikan segmen pasar di Jakarta dan sekitarnya dengan melakukan terobosan baru sehingga konsumen tertarik dan selalu membeli produk yang ada di The Goods Dept.

\section{DAFTAR PUSTAKA}

Buku

Ali, Hasanuddin \& Lilik Purwandi. Millenial Nusantara. Pahami Karakternya Rebut Simpatinya. Gramedia, Jakarta, 2017.

Apriadi, Tamburaka. Literasi Media: Cerdas Bermedia Khalayak Media Massa, Edisi ke-1, Rajawali Pers, Jakarta, 2013.

Durianto, Darmadi. (2001). Strategi Menaklukan Pasar melalui Riset Ekuitas dan Perilaku. Jakarta : PT Gramedia Pustaka Utama.

Fiske, John. Pengantar IImu Komunikasi. Edisi ke-3, Rajawali Pers, Jakarta, 2014.

Kotler, Philip \& Kevin Lane. Manajemen Pemasaran. Edisi ke-1.PT. Prehallindo, Jakarta, 2009.

Liliweri, Alo. 2011. Komunikasi Serba Ada Serba Makna. Kencana Prenada Media Group. Jakarta.

Mardalis. Metode Penelitian Suatu Pendekatan Proposal. Jakarta: Bumi Aksara, 2008.
Morissan. Periklanan: Komunikasi Pemasaran Terpadu, Edisi ke-1, Prenadamedia Group, Jakarta, 2010.

Onong Uchjana Effendy. IImu Komunikasi Teori dan Praktek. Edisi ke-19, PT RemajaRosdakarya, Bandung, 2005.

Patilima, Hamid. 2007. Metode Penelitian Kualitatif. Alfabeta,cv. Bandung.

Peter Paul J dan Jerry C. Olson. Perilaku Konsumen \& Strategi Pemasaran, Edisi ke-9, SalembaEmpat.

Rakhman, Jalaluddin. Metode Penelitian Komunikasi. Bandung: PT Remaja Rosdakarya, 2012.

Samatan, Nuriyati. RisetKomunikasi $I$. Penerbit: Gunadarma. Jakarta. 2017.

Sasa Djuarsa Sendjaja dkk. Teori Komunikasi, Edisi ke-2, Universitas Terbuka, Jakarta, 2008.

Shimp, A. Terance. Integrated Marketing Communications in Advertising and Promotion. Edisi ke-7. Thompson, South Western, 2007.

Sofjan Assauri. Manajemen Pemasaran, Edisi ke-15, Rajawali Pers, Jakarta 2017

Sunyoto, Danang. Manajemen Pemasaran (Pendekatan Konsep, Kasus, dan Psikologi Bisnis) .Edisi ke-1. Yogyakarta, 2013. CAPS (Center of Academic Publishing Service)

Jurnal

Dewi Fatikhatuz Zahro. 2012. Strategi Komunikasi Pemasaran Terpadu Desa Wisata Dalam Meningkatkan Kunjungan Wisatawan. Skripsi. Yogyakarta: Universitas Islam Negri SunanKalijaga

Hamzah Dzilqarnain. 2015. Strategi Komunikasi Pemasaran Universitas Muhammadiyah Magelang. Skripsi. Yogyakarta: Universitas Negri Yogyakarta. 
PriciliaAdji 2013. Pengaruh Retail Mix terhadap Keputusan PembelianMahasiswa UK Petra di Circle K Siwalankerto Surabaya

\section{Internet}

https://www.researchgate.net/publication/32

7628779_Tabayyun_di_Era_Generasi_Mill enial. Diakses pada 7 April 2019

http://marketeers.com/anton-wirjono-thegoods-dept-bukan-untuk-menyamairaksasa-ritel/. Diakses pada 20 maret 2019

https://properti.kompas.com/read/2013/05/2 7/19064845/Nih....Tiga.Pusat.Belanja.Palin g.Ramai.Dikunjungi.Diaksestanggal 18 Maret 2019 